\title{
RADIOCARBON-DATED PALEOENVIRONMENTAL CHANGES ON A LAKE AND PEAT SEDIMENT SEQUENCE FROM THE CENTRAL GREAT HUNGARIAN PLAIN (CENTRAL EUROPE) DURING THE LAST 25,000 YEARS
}

\author{
Pál Sümegi ${ }^{1,2}$ • Mihály Molnár ${ }^{3}$ Gusztáv Jakab ${ }^{4}$ Gergő Persaits ${ }^{1}$ • Péter Majkut ${ }^{1} \bullet$ \\ Dávid G Páll ${ }^{1}$ Sándor Gulyás ${ }^{1}$ A J Timothy Jull ${ }^{5}$ Tünde Törcsik ${ }^{1}$
}

\begin{abstract}
One of Hungary's geological and environmental treasures is nestled in the heart of the Great Hungarian Plain. The catchment basin of Lake Kolon was subjected to detailed environmental historical studies starting in 2005. Undisturbed cores taken along transects of the basin were subjected to detailed sedimentological, paleoecological, and geochemical studies. To establish a reliable timeframe of the lacustrine and marshland sedimentary sequence identified, 22 samples were analyzed by accelerator mass spectrometry (AMS) in the radiocarbon laboratories of Poznań and Tucson. With the new results in hand, we had the opportunity to elucidate the geological evolution of the area for the past 25,000 yr. This sequence is highly beneficial, as it is probably the most well-dated profile of the Quaternary from the area studied. The new absolute dates enabled the comparison of local geological evolution of the studied area with those of global climatic changes. As seen from our findings, the geological evolution of the catchment basin was congruent with major climatic events during the Pleistocene and the entire Holocene. However, a very peculiar trajectory was identified for the terminal part of the Pleistocene and the opening of the Holocene regarding the evolution of the landscape, the vegetation, and the fauna of this part of the Great Hungarian Plain.
\end{abstract}

\section{INTRODUCTION}

Lake Kolon, in the heart of the Carpathian Basin, comprises one of the largest wetland systems in present-day Hungary. The lake itself is located between the floodplain of the modern Danube River and its abandoned alluvial fan covered by windblown sands in the southern part of the Danube-Tisza Interfluve (Figure 1). As a result of drainage activities implemented on the floodplain of the Danube River from the 19th century onwards, the original lacustrine basin was transformed into a wetland with scattered open-water surfaces presently occupying an area of about $30 \mathrm{~km}^{2}$. Over the course of past climatic changes and intensified anthropogenic influences, it was the only lake in the region that managed to overcome the negative effects of these influences and more or less preserved its original wetland character. The modern lake is a highly protected wetland area of the Danube-Tisza Interfluve. It harbors unique fish and avifauna composed of local and migratory birds, as well as several highly protected plant taxa. Thanks to its unique fauna and flora, it is protected as part of the Ramsar Treaty, the Eurosite program, and the Natura 2000 network under the supervision of the Kiskunság National Park.

Several studies have discussed the evolution of the landscape in historical times. However, some of these were based on written historical records, property charts, and maps of the area from the 18th century onwards. Others used the records of botanical surveys implemented in the first and second half of the 20th century (Deli 1989; Molnár and Vajda 2000; Kun and Máté 2002), satellite images, and aerial photographs to assess the most recent transformations of the landscape in order to support protection measures (Keveiné et al. 2004). The geological evolution of the lacustrine basin was also documented relatively early, parallel with the proposal for conservation (Molnár et al. 1979). In

\footnotetext{
${ }^{1}$ University of Szeged, Department of Geology and Paleontology, P.O. Box 658, 6701 Szeged, Hungary.

${ }^{2}$ Archaeological Institute of the Hungarian Academy of Sciences, 1014 Budapest Úri u. 49, Hungary. Corresponding author. Email: sumegi@geo.u-szeged.hu.

${ }^{3}$ Laboratory of Environmental Studies, Institute of Nuclear Research of the Hungarian Academy of Sciences, 4025 Debrecen Bem tér 18/C, Hungary.

${ }^{4}$ Tessedik Sámuel College 5540 Szarvas Szabadság str. 2, Hungary.

${ }^{5}$ NSF Arizona AMS Laboratory, University of Arizona, 1118 East Fourth St., Tucson, Arizona 85721, USA.
} 


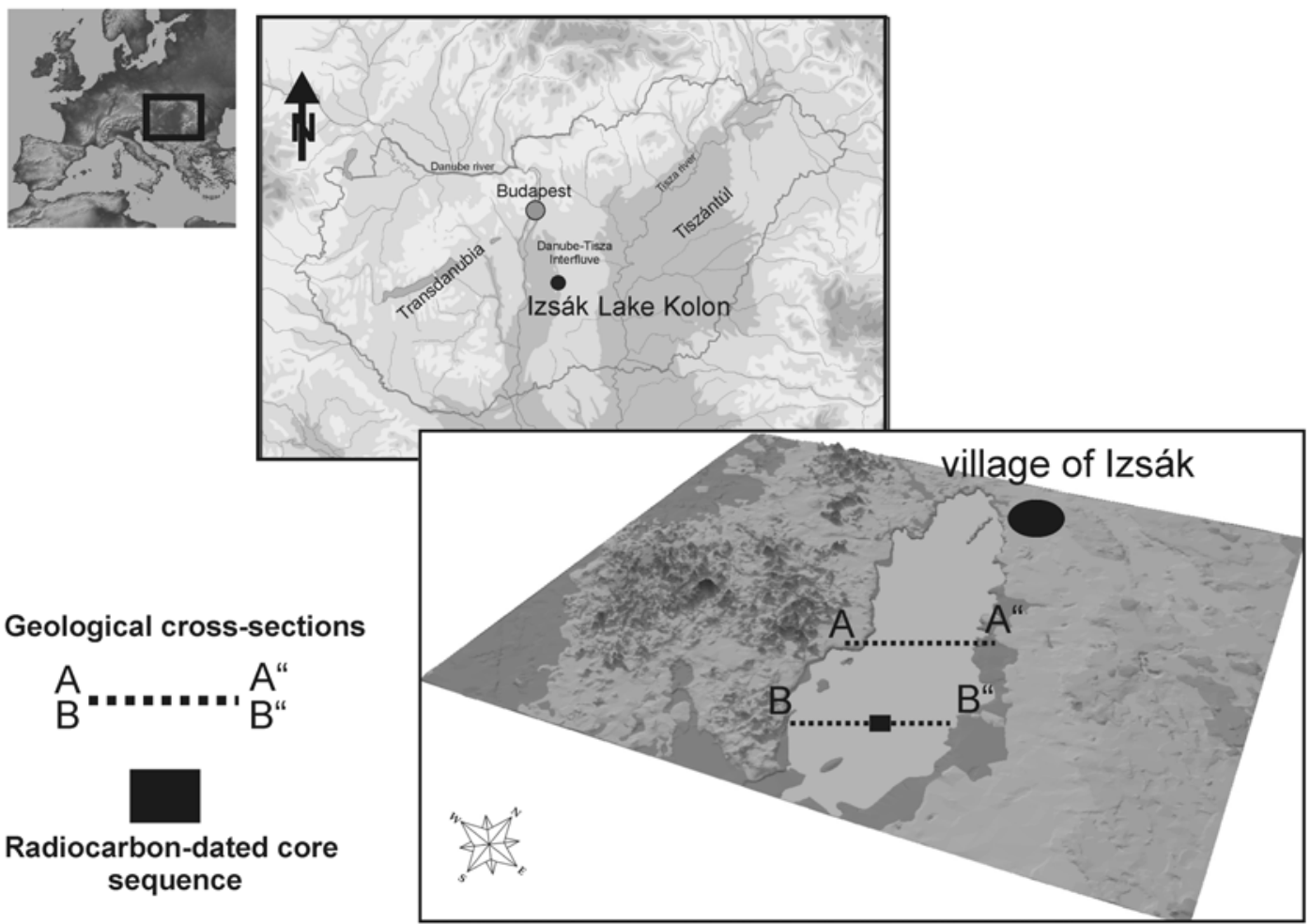

Figure 1 Geographical location of the catchment basin of Lake Kolon in the Danube Valley and the coring site

accordance with the former local geological protocol, the subsurface geology was elucidated via numerous boreholes deepened using the augering technique. Identification of the major geological features was solely based on lithostratigraphy and biostratigraphy lacking absolute dates. Nevertheless, several recent Quaternary paleoecological studies of catchment basins and loess/paleosol sequences from the Carpathian Basin pointed to the fact that the evolution of the flora, fauna, and landscape of the basin was by no means contemporary and uniform throughout the entire basin (Sümegi 2003, 2007). Thus, certain global climatic events might have had a different outcome on a regional and/or local level due to the mosaic-like complexity of the landscape since the Ice Age (Sümegi 2007). To track the effects of these events and synchronize them on a regional and basinwide scale, absolute chronology is necessary. On one hand, the aim of the present study was to reassess the geological evolution of the lake based on absolute dates to create a solid database of Quaternary environmental changes for the region. On the other hand, in light of modern protection measures aimed at restoring the natural conditions of the landscape, it was necessary to determine the speed of sedimentation in the lacustrine basin and the role of autocyclic successions in the creation of the modern protected landscape.

\section{Geological Background}

Lake Kolon is located at the interface of 2 distinct landscapes, the alluvial plain of the Danube River and the adjacent elevated ridge of the Danube-Tisza Interfluve (Figure 1). The Quaternary geological evolution of the referred landscapes is relatively well-documented (Miháltz 1953; Molnár 1961, 2004). To explain the framework of the evolution of the Kolon lake system, a brief overview of the 
geological evolution of the landscape is given here. The river was of great importance in the evolution of the lake and the entire area of the Danube-Tisza Interfluve during the Pleistocene and the Holocene. At the end of the Pleistocene, as a result of regional subsidence, the Danube occupied its modern riverbed, leaving the area of the Danube-Tisza Interfluve behind. The cessation of fluvial sedimentation at the end of the Pleistocene favored the initiation of eolian processes in the area of the Danube-Tisza Interfluve, leading to the deposition of windblown sand dunes with a NW-SE trend. As the climate became more humid during the Holocene, higher discharge reaching the watershed of the Danube River resulted in increased fluvial activities and the encroachment of the river into areas adjacent to the floodplain, forming side-branches. One of these branches corresponds to the basin of Lake Kolon (Figure 1).

\section{MATERIAL AND METHODS}

To establish a sound chronology of the lake's prehistoric evolution and determine the speed of sediment accumulation, undisturbed cores have been taken along 2 geological transects. Samples from a single core deriving from the deepest part of the lake were subjected to detailed sedimentological, geochemical, palynological, plant macrofossil, malacological, and chronological analyses.

The chronological framework was established with the help of 18 samples subjected to accelerator mass spectrometry (AMS) analysis. Sixteen samples were analyzed at the ${ }^{14} \mathrm{C}$ laboratory of the University of Arizona (USA), while 2 samples underwent AMS analysis at the ${ }^{14} \mathrm{C}$ laboratory of Poznań, Poland. From the Upper Würmian section, charcoal pieces of Norway pine (Pinus sylvestris) were utilized. Charcoal is a heterogeneous material and may contain contaminating carboncontaining components (humic substances) yielding older ages (Alon 2002). To asses this potential problem in our work, the acid-alkali-acid (AAA) procedure was adopted to separate humic substances from the charcoal pieces (Hatté et al. 2001). Humic substances were also subjected to AMS analysis parallel to the charcoal to asses any age differences. Conversely, reed fragments (Pragmites australis) isolated from peat were used to date the Late Glacial and Holocene part of the sequence. As one major aim was to give support to lakebed cleaning and restoration measures, an exact determination of sedimentation rates was necessary for the Holocene part of the profile. That is why the majority of samples subjected to chronological analysis come from the uppermost part of the core. In order to allow a comparison with other archaeological and environmental historical data, the received dates were calibrated using the CalPal-2007 online calibration program, using the most upto-date CalPal-2007 ${ }_{\mathrm{Hulu}}$ calibration data set (Weninger et al. 2008). The raw dates $\left({ }^{14} \mathrm{C}\right.$ ) are indicated as BP, while the calibrated dates are indicated as cal BC or cal BP.

For the paleoecological reconstruction, the model of Birks and Birks (1980) was systematically adapted. Sampling was carried out using a 5-cm-diameter Russian-type corer (Jowsey 1966). Overlapping cores were extracted, conforming to the general practice in Quaternary paleoenvironmental studies (Aaby and Digerfeldt 1986). The main lithostratigraphic characteristics of the sedimentary sequence were identified and described using the system and symbols of Troels-Smith (1955) developed for unconsolidated sediments in accordance with international Quaternary paleoecological standards. The grain-size composition was assessed using Casagrande's (1934) aerometric method. The organic and carbonate content of the samples was determined via Dean's loss on ignition (Dean 1974). The inorganic content was further analyzed using the water-extraction method of Dániel (2004) yielding information on paleohydrological changes and soil erosion in the catchment (Sümegi et al. 1999). Elements of Na, K, Ca, Mg, and Fe were analyzed using a PerkinElmer AAS (atomic absorption spectrometer) type, Analyst 100. Samples were processed for pollen at 4-cm intervals (Berglund 2003) with exotic pollen added to each sample to determine the concentration of 
pollen grains (Stockmarr 1971). A minimum count of 500 grains (all pollen plus spores) per sample was made to ensure a statistically significant sample size (Maher 1972). The pollen diagram was divided into local pollen assemblage zones (LPAZ) reflecting the changes of the most important taxa. For the description of macrofossils, a modified version of the QLCMA (semi-quantitative quadrate and leaf-count macrofossil analysis) technique of Barber et al. (1994) and Jakab et al. (2004) was adopted. Identification of herbaceous plant tissues was based on the procedure described by Jakab and Sümegi (2004). The size of subsamples for macrofossil analysis was $3 \mathrm{~cm}^{3}$. Mollusk shells for malacological studies were derived from sediment samples of $1 \mathrm{dm}^{3}$ (Krolopp 1983). The retrieved shells were taxonomically identified using the works of Cameron and Redfern (1976), Kerney et al. (1983), Likharev and Rammelmeier (1964), Ložek (1964), and Soós (1943, 1955). Abundance and dominance values of the individual species were tabulated and specimen and percentage distribution of the individual species with depth were calculated. The dominance values of the individual species were also calculated in relation to the depth. Afterwards, using the works of Sümegi (1989), Krolopp and Sümegi (1992, 1995), and Sümegi and Krolopp (1996), the individual species were clustered into paleoecological and biogeographical groups by taking into account their ecological requirements regarding such parameters as temperature, humidity, and vegetation cover. The ecological works of Ant (1963), Boycott (1934), Evans (1972), Ložek (1964), Meier (1985), and Sparks (1961) on the recent and fossil mollusk faunas as well as the distribution maps and data of Bába (1983, 1986), Ehrmann (1933), Kerney et al. (1983), Klemm (1974), Liharev and Rammelmeier (1964), Ložek (1964), and Soós $(1943,1955)$ have been used for the clustering. The resulting paleoecological and environmental data were graphed using the PSIMPOLL program package of Bennett (1992).

On the basis of the collective evaluation of paleoecological and chronological data, the major stages of the lake's evolution were determined and graphed with main proxies marked, and the rate of sedimentation was calculated for each evolutionary stage.

\section{RESULTS AND DISCUSSION}

Table 1 shows the results of AMS analysis, giving the chronological framework for our interpretations. The sequence yielded successively older ages downwards, and no mixing of the samples was found. On the basis of the results, the uppermost $2 \mathrm{~m}$ represent the Holocene part of the section, while the additional $2 \mathrm{~m}$ of the samples corresponds to the Late Glacial period and the youngest part of the Würmian. For the uppermost sample $(5 \mathrm{~cm})$, no conventional age could be given. For the charcoal samples, no significant differences could be seen in the $\delta^{13} \mathrm{C}$ values of the charcoal and humin samples as well as the received ${ }^{14} \mathrm{C}$ ages, implying little or no alteration of the dated material. In the next section, the observed features are presented in chronological order.

\section{The Upper Würmian Part of the Profile}

The bedrock of the central core was comprised of grayish-yellow, rounded, well-sorted, slightly calcareous windblown sands between 4.4 and $2.8 \mathrm{~m}$ depth (Figures 2-3.) A minor intercalation of a thin layer of reddish-brown paleosol reaching a thickness of about $10 \mathrm{~cm}$, characterized by relatively high clay content and a high abundance of charcoal pieces of Norway pine (Pinus sylvestris), was observed at 4.2-4.1 m. Analyses of these charcoal samples yielded an absolute age of 27,000$25,000 \mathrm{cal}$ yr BP. No significant differences were found between the ages received for the charcoal and the concomitant humic substances, signifying a likely quick coeval deposition and pedogenesis (Table 1). No pollen grains or mollusk remains could be retrieved from this horizon. The inferred rate of deposition was moderately large at $0.42 \mathrm{~mm} / \mathrm{yr}$ (Figure 4). 
Table $1{ }^{14} \mathrm{C}$ ages from core 11 of the Lake Kolon site.

\begin{tabular}{|c|c|c|c|c|c|c|c|}
\hline Lab code & Material & $\begin{array}{l}\text { Depth } \\
\text { (cm) }\end{array}$ & ${ }^{14} \mathrm{C}$ yr & $1 \sigma$ & $\begin{array}{l}\delta^{13} \mathrm{C} \\
\text { (VPDB) } \\
\pm 0.1 \% \text { o }\end{array}$ & cal yr BP & BC/AD yr \\
\hline Poz-23346 & Phragmites & 5 & 116.52 & 0.35 & $\mathrm{n} / \mathrm{a}$ & - & - \\
\hline Poz-23344 & Phragmites & 30 & 410 & 20 & $\mathrm{n} / \mathrm{a}$ & $479-506$ & AD 1444-1470 \\
\hline Poz-23345 & Phragmites & 40 & 1005 & 35 & $\mathrm{n} / \mathrm{a}$ & $854-880$ & AD 993-1097 \\
\hline AA79670 & Phragmites & 50 & 2668 & 40 & -27.1 & $2762-2830$ & 812-880 BC \\
\hline AA79671 & Phragmites & 55 & 2864 & 36 & -27.3 & 2936-3050 & 986-1100 BC \\
\hline AA79669 & Phragmites & 60 & 4137 & 38 & -26.6 & $4602-4786$ & 2652-2836 BC \\
\hline AA79668 & Phragmites & 65 & 4396 & 39 & -26.4 & 4901-5035 & 2951-3075 BC \\
\hline AA79667 & Phragmites & 70 & 4777 & 41 & -26.5 & 5479-5574 & 3530-3624 BC \\
\hline AA79666 & Phragmites & 75 & 5585 & 41 & -27.8 & 6326-6403 & 4377-4463 BC \\
\hline AA79665 & Phragmites & 80 & 6559 & 43 & -26.5 & $7442-7505$ & 5555-5493 ВC \\
\hline AA79664 & Phragmites & 85 & 7578 & 45 & -26.9 & 8366-8414 & 6464-6416 BC \\
\hline AA79663 & Phragmites & 100 & 8673 & 57 & -27.3 & 9575-9718 & 7626-7768 BC \\
\hline AA79662 & Phragmites & 120 & 9149 & 58 & -27.9 & $10,260-10,405$ & 8311-8455 BC \\
\hline AA79661 & Phragmites & 170 & 9678 & 51 & -27.7 & $10,901-11,173$ & 8951-9223 ВС \\
\hline AA79660 & Phragmites & 221 & 11,573 & 58 & -27.9 & $13,342-13,571$ & 11,393-11621 BC \\
\hline AA79659 & Pinus charcoal & 279 & 17,871 & 99 & $-28,6$ & $21,092-21,808$ & 19,142-19858 BC \\
\hline AA79657 & Humin acid & 279 & 19,700 & 118 & -27.9 & $23,257-23,849$ & 21,307-21,899 BC \\
\hline AA79658 & Pinus charcoal & 415 & 21,047 & 134 & -28.1 & $24,811-25,588$ & $22,862-23,638$ BC \\
\hline AA79656 & Humin acid & 415 & 21,907 & 155 & -27.5 & $25,874-26,690$ & $23,924-247,40 \mathrm{BC}$ \\
\hline
\end{tabular}

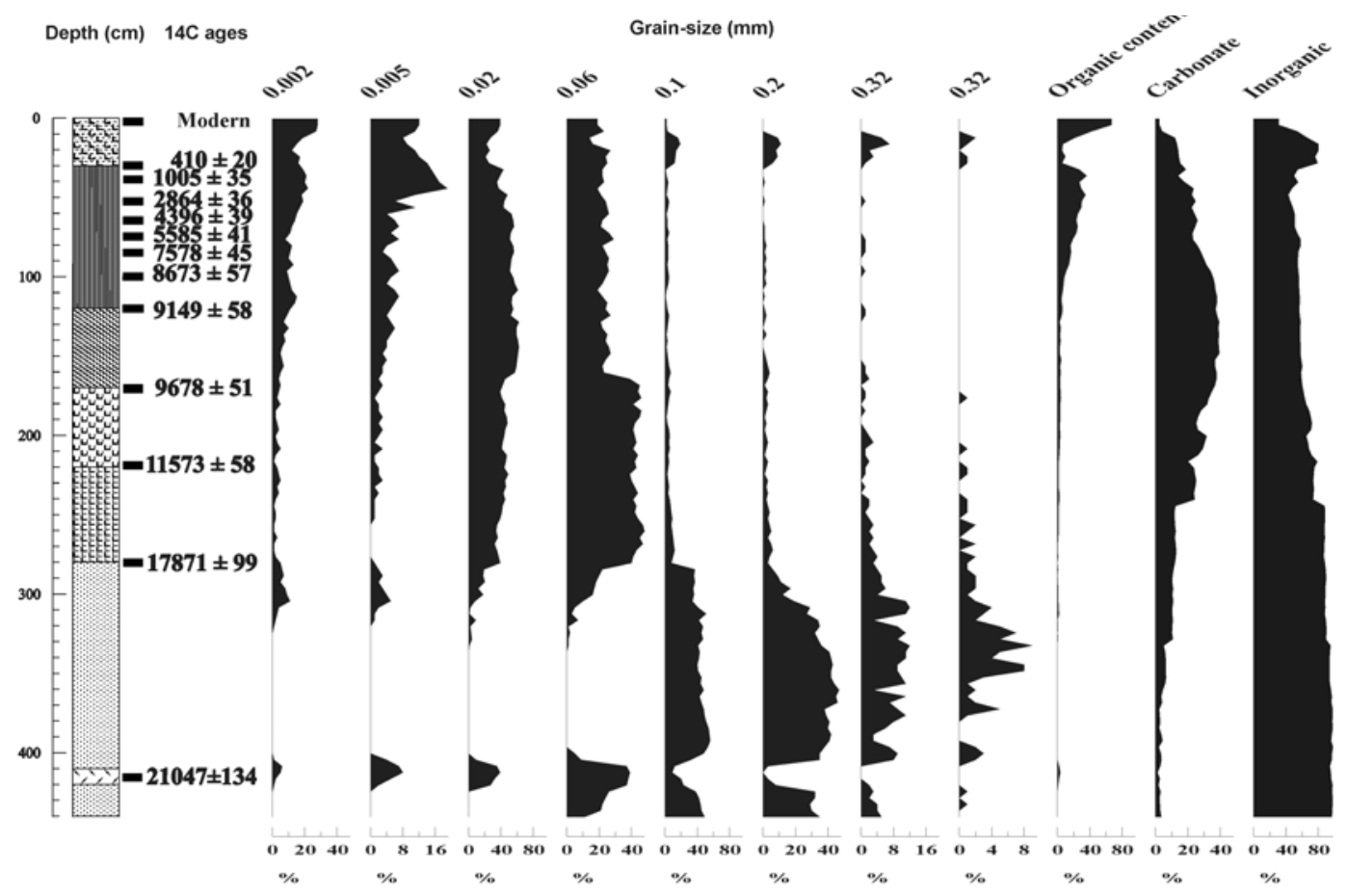

Figure 2 Results of grain-size analysis and loss on ignition (LOI) for the ${ }^{14} \mathrm{C}$-dated core 11 


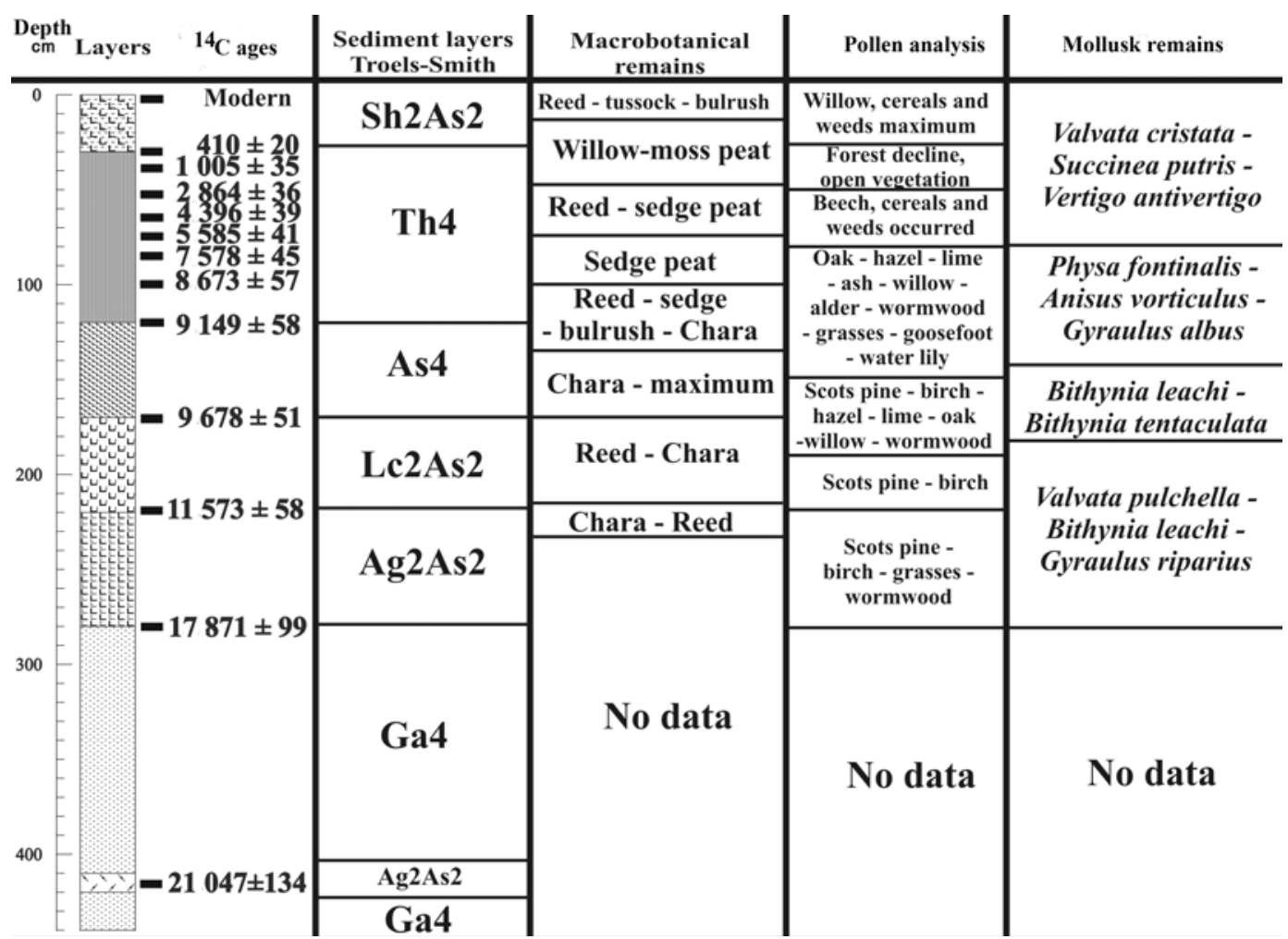

Figure 3 Results of sedimentological, plant macrofossil, palynological, and malacological analyses for the ${ }^{14} \mathrm{C}$-dated core 11

Windblown sands are overlain by silty, calcareous, and highly fossiliferous light-gray "minerogenic" lacustrine deposits between 2.8 and $2.2 \mathrm{~m}$ depth (Figures 2-3). These lacustrine deposits were inferred to have developed between 24,000-14,000 cal yr BP. The evolution of these minerogenic deposits must be linked to the deposition of eolian dust in a coldwater lacustrine setting (Oldfield 1977) as reflected by the significant amount of the silt fraction. Yet, accumulation rates were the lowest here, identified in the whole profile of $0.07 \mathrm{~mm} / \mathrm{yr}$, congruently with the expected low rate of dust deposition under cold climate. The larger amount of sands identified in these deposits result from the transportation of a considerable portion of windblown sands from the shore areas to the basin during the referred period.

The Upper Würmian lacustrine sequence yielded pollen grains poor in species but with a relatively good preservation state. The material was dominated by the grains of various grass taxa (Gramineae), pines (Pinus), goosefoots (Chenopodiaceae), and Artemisia (Artemisia) (Figure 3). This record thus seems congruent with the general pollen picture drawn for the area of the Great Hungarian Plain for the Upper Würmian (Sümegi et al. 1999). Nevertheless, the presence of such taxa as birch (Betula), including dwarf birch (Betula nana), alder (Alnus), and willow (Salix), gaining importance in some parts marks the emergence of somewhat special local conditions different from the major regional picture. The proportion of pine pollen grains exceeded $50 \%$ in the material even during the cold maximum of the Upper Würmian. This can be attributed to the relatively large size of the catchment basin of Lake Kolon with its estimated water coverage of $60 \mathrm{~km}^{2}$. This likely enabled the trapping of significant amounts of pine pollen grains of extra-local origin. The studied system must have been connected to the active riverbed of the Danube during the referred Ice Age 
period, and as a result, a large mass of floating pine pollen grains could have been transported into the lacustrine basin via floodwaters (Fall 1987). Thus, the pollen picture drawn for the Upper Würmian represents a highly disturbed system reflecting composition of the wider regional vegetation rather than that of the local vegetation as a result of selective pollen accumulation by floodwaters in a relatively large catchment basin of an oxbow lake. On the basis of the retrieved pollen grains, open parkland-type vegetation could have been reconstructed with patches of alkaline Artemisia grasslands along the lake during the Upper Würmian. The woodland areas were likely composed of stands of pine, dwarf pines, willow, birch, and alder, forming a gallery woodland along the shore. The nearshore aquatic vegetation were composed of various sedge taxa. This would indicate a mosaic-like mixing of cold tundra and taiga elements in accordance with the geomorphology and height of the groundwater table, creating a so-called hydro series. The unique geomorphology of the area led to a complex microclimate enabling the collective existence of cold tundra, taiga, and temperate grassland and woodland as well as aquatic elements at the site during the Upper Würmian.

Among the non-arboreal vegetation elements, the presence of numerous aquatic taxa were attested for this period (Figure 3). Identification of the algae taxon Pediastrum kawayskii is significant, as the presence of this species presently harboring in the fluvial system of the German-Polish Plains marks the evolution of an open-water lacustrine system in our study area with a minimum water depth of $3 \mathrm{~m}$ for the Upper Würmian. The relatively low abundance of plant macrofossil remains in the Upper Würmian deposits imply scant nearshore aquatic vegetation and a relatively high water level. The lakebed bottom was covered by a mat of Chara algae, dominated by Chara vulgaris. The nearshore aquatic vegetation was composed of reeds and various cold-resistant sedge taxa (Carex rostrata, Carex acutiformis) and various types of equiseta (Equisetum fluitans). A characteristic ostracod species of this period is Ilyocypris gibba, preferring muddy substrates and deeper lacustrine systems.

The aquatic mollusk fauna was dominated by cold-loving and cold-resistant species preferring oligotrophic conditions (Valvata pulchella, Bithynia leachi, Anisus leucostoma, and Gyraulus riparius) (Figure 3). The accessory elements include such taxa as Lymnaea stagnalis, Aplexa hypnorum, and Armiger crista. The terrestrial mollusk fauna was likewise dominated by cold-loving, ditch species of Succinea oblonga, marking the evolution of a cold, oligotrophic lake system with clean, oxygenrich bottom conditions composed of unweathered silicates. Based on modern analogies (Oklan 1990) regarding the composition of aquatic fauna, the inferred depth of this cold Ice Age lake must have exceeded $3 \mathrm{~m}$.

\section{Late Glacial Part of the Profile}

There is a gradual increase in the clay and carbonate content of the deposits from about 2.2 to $1.7 \mathrm{~m}$ depth. This was accompanied by a sudden drop in the sand content, as well as a decrease in inorganic matter, indicating intense weathering and pedogenesis in the nearshore areas and the inwash of the resulting weathered mass into the lacustrine basin (Figures 2-3). This is observable in the elevated rate of accumulation of $0.26 \mathrm{~mm} / \mathrm{yr}$ compared to the previous zone marking the transformation of the lake system into a carbonate-rich mesotrophic lake (Figure 4). Such major transformations in the sedimentology were connected to pronounced climatic and environmental changes, most likely as a result of improving climate conditions. As shown by the radiocarbon data (Table 1), these transformations began around 13,000-14,000 cal BP and persisted as late as 11,000 cal BP. In terms of relative chronology, this mesotrophic lake horizon thus corresponds to the Late Glacial period.

This zone is characterized by low concentrations of plant macrofossil remains, indicating a rise in the water level, parallel with a noticeable decrease in reed remains (Figure 3). This decrease in plant 


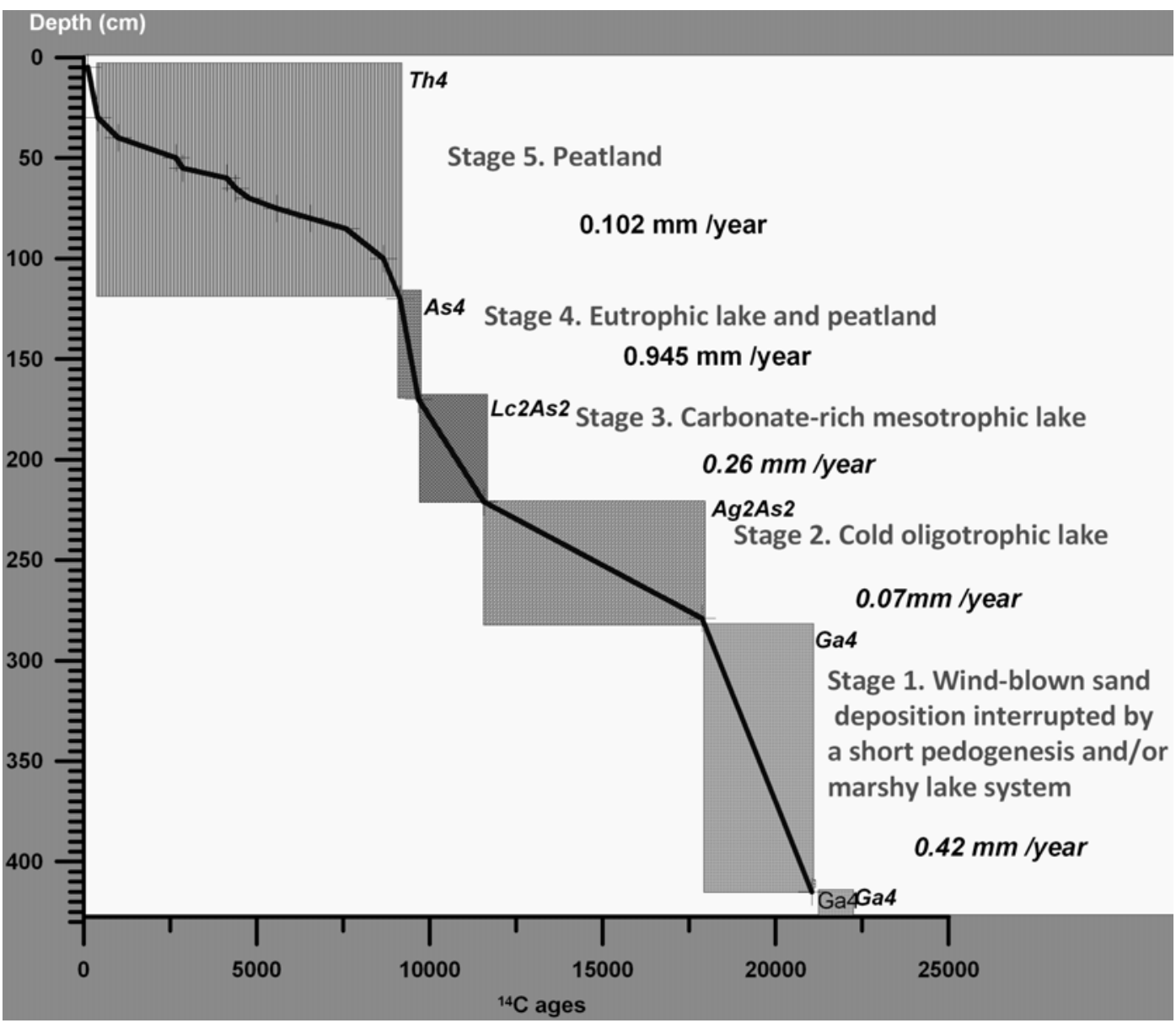

Figure 4 The inferred rate of sedimentation for individual stages of the lake’s evolution

macrofossils was accompanied by an increase in ostracod, mollusk, and calcareous algae remains. Among the algae, the presence of Chara vulgaris and C. contraria was expected. The ostracod fauna was relatively rich in species within this zone, highlighted by Ilyocypris gibba, Paracandona euplectella, Metacypris cordata, and Candona, Cyclocypris, and Eucypris. This unique composition of ostracod fauna marks the development of a permanent water cover in the lacustrine basin with somewhat elevated water levels. On the basis of some Betula epidermis remains retrieved, the presence of birch in the shore vegetation can be inferred.

The pollen material of the Late Glacial deposits was characterized by a dominance of pine and birch grains along with those of grasses (Gramineae) and Artemisia (Figure 3). This implies that the vegetation composition of the Upper Würmian was preserved with a major increase in the ratio of arboreal pollens (APs), marking the emergence of a closed gallery woodland composed of pines and birches on the lakeshore. Meanwhile, the distal windblown sand-covered natural peaks harbored alkaline grasslands dominated by Artemisia. Thus, due to possible spatial differences in the groundwater table heights, 2 highly distinct vegetation types could be reconstructed for the Late Glacial.

The mollusk fauna was also similar to the previous Upper Würmian with a gradual transition in the dominance of certain elements and the general composition towards the terminal part of the Late 
Glacial. This period was an acme for the oligotrophic, cold-resistant aquatic elements of the terminal Pleistocene (Figure 3). Nevertheless, despite some minor transformations by the terminal Late Glacial, this fauna is sharply different from the succeeding Holocene mollusk fauna of the site.

\section{Holocene Part of the Profile}

There is a pronounced transformation in the sedimentology and paleoecology of the sequence between 1.6 and $1.7 \mathrm{~m}$ depth, corresponding to the period 10,900-11,000 cal yr BP. There is a sharp increase in the carbonate, clay, and fine silt content of the deposits along with that of the organic matter in this horizon (Figure 2). Similar changes could have been inferred for the central parts of the Carpathian Basin as well between about 11,000-10,000 yr BP, probably marking rising temperatures and the emergence of climatic conditions characterizing the Holocene period. Conditions characterizing the area even today must have developed during this time period. As a result of gradually increasing temperatures, the cold-water oligotrophic lake was gradually transformed into a temperate eutrophic lake characterized by the accumulation of dark gray lacustrine mud of higher clay and organic content (Figures 2-3). The horizon of eutrophic lacustrine deposits of higher clay, organic, and carbonate content was identified between the depths of 1.6 and $1.2 \mathrm{~m}$ (Figures 2-3). Accumulation rates inferred were the highest in this Early Holocene part of the profile with a rate of $0.945 \mathrm{~mm} / \mathrm{yr}$. There is a complete transformation in the sedimentology from about 10,300 $\pm 100 \mathrm{cal}$ $\mathrm{BP}$, characterized by the advent of reed and the incipient accumulation of peat from $1.2 \mathrm{~m}$ depth. This zone is also distinguished by elevated accumulation rates of $0.102 \mathrm{~mm} / \mathrm{yr}$ (Figure 4).

The early Holocene part of the sequence is marked by a complete turnover in the terrestrial vegetation, characterized by the retreat and disappearance of tundra and taiga elements parallel to the advent of various thermophylous, mesophylous deciduous woodland species (Corylus - hazel, Tilia - lime, Ulmus - elm, Quercus - oak) (Figure 3). There is a marked increase in the ratio of water bank elements among the arboreal pollens (APs) within this horizon as well (Salix - willow, Alnus alder, Betula - birch). Despite the pronounced transformation in the APs, non-arboreal pollen taxa characterizing the previous periods like Poaceae and Artemisia remained equally important in the pollen material, implying the survival of temperate grasslands in a temperate open parkland setting along the lake. This horizon also corresponds to a transition of the Pleistocene hydro series in the vegetation to the modern Holocene hydro series composed of deciduous woodlands studded by alkaline grasslands.

The lakeshore harbored a forest of hardwood and softwood elements behind a zone of sedge, reed, and bulrush fringing the lake basin itself. Based on the observed paleoenvironmental features, a drop in the water level could be inferred for this period. Consequently, along with the gradually increasing vegetation cover, large amounts of organic matter could have accumulated in the catchment basin of the lake during this period, probably accompanied by a decrease in the frequency of floods and the isolation of the lake basin from the active channels of the adjacent Danube River. As a result of a major drop in the water level and gradually increasing temperatures, the nearshore areas of the lake likely experienced periodic desiccation, initiating the precipitation of freshwater carbonate mud from the Early Holocene onwards in the lake basin. Due to the periodic desiccation of the nearshore areas, pollen grains were preserved only in the central parts of the catchment basin, which enjoyed continuous water coverage.

The early Holocene zone is characterized by higher plant macrofossil concentrations as well, concomitantly with a dominance of ostracod and mollusk remains. However, there is a marked increase in the number of reed rhizomes, implying the advent of lakeshore reed communities parallel with the preservation of relatively higher water levels in the central parts. The first ash peak was also identi- 
fied towards the end of the zone at a depth of $1.05 \mathrm{~m}$. The amount of algae was also high with the dominance of such taxa as Chara vulgaris, Chara contraria, and Nitellopsis obtusa. The most characteristic ostracod elements are those of Paracandona euplectella and Metacypris cordata. Besides reeds, the presence of numerous sedge taxa like Carex elata, C. acutiformis, C. rostrata, and flagellaria (Juncus sp.) could have been evident. The first moss species also turn up in this zone (Drepanocladus aduncus) (Figure 3). The presence of Senecio paludosus at $1.05 \mathrm{~m}$ is an ecological hallmark referring to the emergence of paludifying reeds or fresh wet meadows in the nearshore areas of the former lake.

The aquatic mollusk fauna was also characterized by the dominance of Holocene elements (Bithynia tentaculata, Physa fontinalis, and Gyraulus albus) (Figure 3). Nevertheless, a clear gradual transformation is discernible in this new mollusk fauna as well, probably connected to the gradual eutrophication then paludification of the lake and the emergence of a peatland in the area. Three distinct subperiods (or biostratigraphically speaking, zonulas) can be identified in the evolution of the Holocene mollusk fauna: the Pleistocene/Holocene transition marked by the Bithynia leachi-Bithynia tentaculata zonula; the Early Holocene Physa fontinalis - Anisus vorticulus - Gyraulus albus zonula; and the zonule of Valvata cristata - Succinea oblonga - Vertigo antivertigo appearing from the Early Bronze Age into the second half of the Holocene. However, the gradual transitions characterizing the evolution of the Pleistocene fauna are not as pronounced in the Holocene part of the section.

The Early Holocene part of the studied profile was characterized by deposition of organic-rich lacustrine sequences, exchanged by the accumulation of peat from the Middle Holocene. Based on the pollen composition, a long-lasting period of the Holocene climatic optimum with higher precipitation and temperatures can be inferred for the area spanning several millennia. The characteristic transformation in the sedimentology during this climatic optimum thus was the outcome of natural succession of paludification and cannot be connected to any major climatic change.

The first appearance of various weed pollen grains (Plantago, Plantago lanceolata, Achillea, Chenopodiaceae) between depths of $0.8-0.9 \mathrm{~m}$, along with various cereal pollen grains, mark the appearance of human agricultural activities in the area. However, as the diameter of the lake exceeded $200 \mathrm{~m}$, ideal for accumulation of pollen grains of local origin during this period (Jacobson and Bradshaw 1981), we cannot say for sure whether crop farming started along the shores during the Early Neolithic or somewhat later. Conversely, the firm appearance of agriculture from the 6th millennium BC can be corroborated on a regional scale.

There is a marked transformation in the vegetation parallel with the appearance of crop cultivation and animal husbandry seen in the decrease of certain arboreal pollens (APs) like hazel, oak, elm, lime, and willow. This was accompanied by an increase in such elements as beech, hornbeam, alder, and birch. This must hallmark the cessation of the climatic optimum and the emergence of a longer, climatically more balanced period characterized by somewhat drier and cooler conditions during the second half of the Holocene.

The ratio of cereal pollen grains remained relatively constant until the Middle-Late Bronze Age. This may imply a dominance of transhumance pastoral activities over crop cultivation in the vicinity of the lake basin from the 6th millennium BC. This was also a period that marked a transition in the aquatic habitat with a clear advent of peatlands. The intensified paludification and the onset of peatlands were caused by climate-induced agricultural shifts. An increase in the stock due to favorable climatic conditions with more precipitation triggered intensified erosion in the direct vicinity of the catchment basin, promoting eutrophication leading to the emergence of alternating peatland and open-water areas within the catchment basin of Lake Kolon. These conditions were preserved up to 
the 19th century when peat mining and drainage measures fundamentally altered the natural conditions in the lake. A major part of the area dried up, contributing to the recurring windblown sand movements. These windblown sands managed to take over a major part of the lake basin as well. Nevertheless, ideal hydrological conditions in the center of the basin enabled the continuation of peat accumulation up to modern times.

\section{SUMMARY OF FINDINGS AND CONCLUSION}

Based on the collective evaluation of paleoecological and environmental data retrieved from cores extracted from the catchment basin of Lake Kolon, the following geological history of the site could be established (Figures 3-4).

As shown by our chronological results, the lake basin emerged about 25,000 BC in an abandoned ice-age channel of the Danube River. Significant amount of calcareous windblown sands were deposited into this abandoned paleochannel. The northern areas of the paleochannel were characterized by intensive pedogenesis giving rise to a paleosol layer overlying the windblown sand embedding remains of Norway pine. Conversely, the southern part of the paleochannel turned into a marshy lake system. These conditions developed between 22,000 and 20,000 yr BP (22,800-24,800 cal BC). The lake itself was fringed by open parkland vegetation composed of pine stands and open grassy spots with Artemisia.

This period was again followed by intense sand deposition. There is a marked change at 17,900 BP $(19,142-19,858$ cal BC) in the geology, characterized by the accumulation of lacustrine deposits leading to the development of silty, minerogenic lacustrine layers. The basin was fringed by mixed sedge-reed aquatic vegetation during this period, while the basin itself hosted thriving Chara vegetation. Further from the shore, mixed open parkland emerged harboring stands of birch and pine. The aquatic mollusk fauna was dominated by cold-loving elements of Gyraulus riparius and Valvata pulchella, both of which went extinct at the end of the Ice Age. The lake was characterized by the deposition of minerogenic sediments for an additional 7000-7200 calendar yr.

This oligotrophic lacustrine system gradually transformed into a carbonate-rich, mesotrophic lake at around 11,600 BP (11,393-11,621 cal BC). This system was characterized by intense accumulation of lacustrine marls embedding Chara fragments up to 9100 BP (8311-8455 cal BC). This phase was characterized by the advent of thermophylous and mesophylous woodland elements into the area (oak, elm, ash, lime, and hazel), giving rise to a highly mixed deciduous woodland with stands of pine around the lake. Aquatic plants marking a gradual warming of the water body also turn up (Nymphaeacea) along with warmth-loving mollusks (Bithynia leachi, Anisus vorticulus). The bottom of the lake was covered by a thick mat of Chara mosses. The basin itself was fringed by reeds, sedges, and bulrush. The accumulation of lacustrine marls lasted from the terminal part of the Ice Age until the first part of the Holocene, for about 3100-3400 calendar yr.

There is a marked change in the sedimentology at $9100 \mathrm{BP}$ (8311-8455 cal BC) characterized by the complete cessation of marl deposition and the initiation of peat accumulation. As shown by the plant macrofossils, this period was marked by the advent of reed, sedge, bulrush, and other tussock elements conquering almost the entire lacustrine basin. The period of the Holocene climatic optimum here thus witnessed the evolution of a peatland in the area. This transformation is also observable in the aquatic mollusk fauna characterized by an advent of warmth-loving ditch species preferring organic-rich waters (Anisus vorticulus, Gyraulus albus), and other marshland-dwellers (Valvata cristata, Vertigo antivertigo). The initiation of peat formation was accompanied by a sharp increase in the proportion of pollen grains of deciduous trees and bushes, marking the closure of woodlands 
and the complete disappearance of coniferous elements at around $9000 \mathrm{BC}$. The areas located further from the lakeshore were hosting steppe-forest-steppe type vegetation.

Signs of the first human influences in the area can be seen at 7500 BP (6464-6416 cal BC), marked by a sharp rise in the concentration of cereal and weed pollen grains, as well as the intense shoaling of the lake basin as a result of accelerated soil erosion in the adjacent areas. As seen in the records of flue-ash, intensive deforestation took place in the vicinity of the lake at the turn of the Copper and Bronze Ages, resulting in the creation of open grasslands with Artemisia from about 3600-2600 BC. These conditions were preserved up to the 19th century, when as a result of the river regulations and drainage measures, a major part of the area dried up, contributing to the recurring windblown sand movements. These windblown sands managed to conquer a major part of the lake basin as well. Nevertheless, ideal hydrological conditions in the center of the basin enabled the continuation of peat accumulation up to modern times.

Based on our calculated sedimentation rates and the identification of natural successions in the paludification process, restoration and preservation of conditions characterizing the area for the past 5000 calendar yr is advised and desirable.

\section{ACKNOWLEDGMENTS}

The authors are greatly indebted to colleagues working at the editorial board of Radiocarbon for making this publication feasible. We are also grateful to Csaba Tóth for lending a hand in the fieldwork. The comments of Prof Béla Molnár and Dr Miklós Szónoky helped a lot in improving the content of this manuscript. Thank you to the anonymous reviewers for their useful comments on the initial draft. This work was partially supported by the headquarters of the Kiskunság National Park. Partial financial support was gained from the fund TÁMOP-4.2.1/B-09/1/KONV-2010-005.

\section{REFERENCES}

Aaby B, Digerfeldt G. 1986. Sampling techniques for lakes and bogs. In: Berglund BE, editor. Handbook of Holocene Paleoecology and Paleohydrology. Chichester: John Wiley \& Sons. p 181-94.

Alon D, Mintz G, Cohen I, Weiner S, Boaretto E. 2002. The use of Raman spectroscopy to monitor the removal of humic substances from charcoal; quality control for ${ }^{14} \mathrm{C}$ dating of charcoal. Radiocarbon 44(1): $1-11$.

Ant H. 1963. Faunistische, ökologische und tiergeographische Untersuchungen zur Verbreitung der Landschnecken in Nordwestdeutschland. Abhandlungen des Landesmuseums für Naturkunde [Münster] 25: 125.

Bába K. 1983. A Szatmár-Beregi sík szárazföldi csigái és a környezetükre levonható következtetések. Acta Academiae Paedagogienis. Szeged: Series BiologicaGeographica 12. p 27-41.

Bába K. 1986. Magyarország szárazföldi csigáinak állatföldrajzi besorolásához felhasznált faj-area térképek. II. Folia Musei Historico-Naturalis Musei Matraensis 11:49-69.

Barber KE, Chambers FM, Maddy D, Brew JS. 1994. A sensitive high-resolution record of the Holocene climatic change from a raised bog in northern England. The Holocene 4(2):198-205.
Bennett KD. 1992. PSIMPOLL-A quickBASIC program that generates PostScript page description files of pollen diagrams. INQUA Commission for the Study of the Holocene: Working Group on Data Handling Methods, Newsletter 8:11-12.

Berglund BE. 2003. Human impact and climate changes-syncronous events and a causal link? Quaternary International 105(1):7-12.

Birks HJB, Birks HH. 1980. Quaternary Palaeoecology. Baltimore: University Park Press. 289 p.

Boycott AE. 1934. The habitats of land Mollusca in Britain. Journal of Animal Ecology 22(1):1-38.

Cameron RAD, Redfern M. 1976. British Land Snails. London: Academic Press. 62 p.

Casagrande A. 1934. Die Aerometer-Methode zur Bestimmung der Kornverteilung von Böden und anderer Materialien. Berlin. 250 p.

Dániel P. 2004. Methods of the five-step extraction method. In: Sümegi P, Gulyás S, editors. The Geohistory of Bátorliget Marshland. Budapest: Archeolingua. p 53-6.

Dean WE. 1974. Determination of carbonate and organic matter in calcareous sediments and sedimentary rocks by loss on ignition; comparison with other methods. Journal of Sedimentary Petrology 44(1): 242-8. 
Deli Gy. 1989. Az izsáki Kolon-tó és növénytársulásai. Kecskemét: Aqua Press. 31 p.

Ehrmann P. 1933. Weichtiere, Mollusca. Tierwelt Mitteleuropas II. Leipzig: Quelle-Meyer. 264 p.

Evans JG. 1972. Land Snails in Archaeology. London: Seminar Press. 436 p.

Fall PL. 1987. Pollen taphonomy in a canyon stream. Quaternary Research 28(3):393-406.

Hatté C, Morvan J, Noury C, Martine P. 2001. Is classical acid-alkali-acid treatment responsible for contamination? An alternative proposition. Radiocarbon 43(2A):177-82.

Jacobson Jr GL, Bradshaw RHW. 1981. The selection of sites for paleovegetational studies. Quaternary Research 16(1):80-96.

Jakab G, Sümegi P. 2004. A lágyszárú növények tzegben található maradványainak határozója mikroszkópikus bélyegek alapján. Kitaibelia 9(1):93-129.

Jakab G, Sümegi P, Magyari E. 2004. A new paleobotanical method for the description of Late Quaternary organic sediments (mire-development pathways and palaeoclimatic records from S Hungary). Acta Geologica Hungarica 47(4):1-37.

Jowsey PC. 1966. An improved peat sampler. New Phytologist 65(2):245-8.

Kerney MP, Cameron RAD, Jungbluth JH. 1983. Die Landschnecken Nord- und Mitteleuropas. Berlin: P Parey. 384 p.

Keveiné BI, Szebellédi T, Bíró Cs. 2004. Tájváltozások a Kolon-tó környékén. Földtani Kutatás 41:35-40.

Klemm W. 1974. Die Verbeitung der rezenten Land-Gehause-Schnecken in Österreich. Denkschriften der Österreichischen Akademie der Wissenschaften Mathematisch-Naturwissenschaftliche 117:1-513.

Krolopp E. 1983. Biostratigraphic division of Hungarian Pleistocene formations according to their mollusc fauna. Acta Geologica Hungarica 26:62-89.

Krolopp E, Sümegi P. 1992. A magyarországi löszök képzdésének paleökológiai rekonstruckiója Mollusca fauna alapján. In: Ször Gy, editor. Fáciesanalitikai, paleobiogeokémiai és paleoökológiai kutatások. Debrecen: MTA Debreceni Akadémiai Bizottság. p 24763.

Krolopp E, Sümegi P. 1995. Palaeoecological reconstruction of the Late Pleistocene, based on Loess malacofauna in Hungary. GeoJournal 36:213-22.

Kun A, Máté A. 2002. A Kiskunsági Nemzeti Park ex lege láp nyilvántartásba vett egyes turján-vidéki területeinek botanikai állapotfelmérése. Méntelek [unpublished research report]. p 65-81.

Likharev IM, Rammelmeier ES. 1964. Nazémnimi molluskami na CCCP. Moscow: Akadémia Nauka CCCP. $574 \mathrm{p}$.

Ložek V. 1964. Quartärmollusken der Tschechoslowakei. Prague: Rozpravy Ústredniho ústavu geologického 31. 374 p.

Maher Jr LJ. 1972. Nomograms for computing 0.95 con- fidence limits of pollen data. Review of Paleobotany and Palynology 13(2):85-93.

Meier T. 1985. The pre-Weichselian nonmarine molluscan fauna from Maastricht-Belvédere (southern Limburg, the Netherlands). Mededelingen Rijks Geologische Dienst 39:75-103.

Miháltz I. 1953. A Duna-Tisza köze déli részének földtani felvétele. MÁFI Jelentése 1950-rl:113-44.

Molnár B. 1961. A Duna-Tisza-közi eolikus rétegek felszíni és felszínalatti kiterjedése. Földtani Közlöny 91:303-15.

Molnár B. 2004. A Duna-Tisza közi hátság negyedidszak végi fejldéstörténete. Földtani Kutatás 41:26-35.

Molnár B, Iványosi Szabó A, Fényes J. 1979. A Kolontó kialakulása és limnogeológiai fejldése. Hidrológiai Közlöny 12:549-59.

Molnár Z, Vajda Z. 2000. A Duna-Tisza köze élhely térképezése. Vácrátót-Kecskemét: Aqua Press. 31 p.

Oklan J. 1990. Lakes and Snails. Environment and Gastropoda in 1500 Norwegian Lakes, Ponds and Rivers. Oegstgeest: Backhuys Publishers.

Oldfield F. 1977. Lakes and their drainage basin as units of sediment-based ecological study. Progress in Physical Geography 1(3):460-504.

Soós L. 1943. A Kárpát-medence Mollusca faunája. Budapest: Akadémiai Kiadó. 478 p.

Soós L. 1955. Puhatestek. In: Székessy A, editor. Fauna Hungariae. Budapest: Akadémiai Kiadó. 19.1: p 132; 19.2: p 1-80; 19.3: p 1-158.

Sparks BW. 1961. The ecological interpretation of Quaternary non-marine Mollusca. Proceedings of the Linnean Society of London 172:71-80.

Stockmarr J. 1971. Tablets with spores used in absolute pollen analysis. Pollen et Spores 13:615-21.

Sümegi P. 1989. A Hajdúság fels-pleisztocén fejldéstörténete finomrétegtani (slénytani, szedimentológiai, geokémiai) vizsgálatok alapján $[\mathrm{PhD}$ dissertation]. Debrecen: Kossuth University. 96 p.

Sümegi P. 2003. A régészeti geológia és a történeti ökológiai alapjai. Szeged: JATE Press. 215 p.

Sümegi P. 2007. Magyarország negyedidszak végi környezettörténete. Szeged-Budapest: MTA Doktori Értekezés. 343 p.

Sümegi P, Krolopp E. 1996. A magyarországi Würm korú löszök képzdésének paleoökológiai rekonstrukciója Mollusca fauna alapján. Földtani Közlöny 124:125-48.

Sümegi P, Magyari E, Daniel P, Hertelendi E, Rudner E. 1999. A kardoskúti Fehér-tó negyedidszaki fejldéstörténetének rekonstrukciója. Földtani Közlöny 129:479-519.

Troels-Smith J. 1955. Karakterisering af lose jordater [Characterization of unconsolidated sediments]. Danmarks Geologiske Undersogelse series IV(10):55-63.

Weninger B, Jöris O, Danzeglocke U. 2008. CalPal2007. Cologne radiocarbon calibration \& palaeoclimate research package. http://www.calpal.de/. 